 およびアニオン交換法による Ce(IV) の分離”
}

\author{
新井 㓮 ${ }^{1}$ 韋 悦 周 $^{2}$ 熊 谷 幹 郎 $^{3}$ \\ 三瓶友 広 ${ }^{4}$ 武田邦 彦 ${ }^{5}$
}

\section{Electrolytic Oxidation of Ce(III) to Ce(IV) in Nitric Acid Solution and Separation of Ce(IV) by Anion Exchange Method}

by Tsuyoshi ARAI ${ }^{\mathrm{a}}$, Yuezhou WEI ${ }^{\mathrm{a}}$, Mikio KUMAGAI ${ }^{\mathrm{b}}$, Tomohiro SANPEI ${ }^{\mathrm{c}}$ and Kunihiko TAKEDA ${ }^{\mathrm{d}}$

a. Nuclear Chemistry and Chemical Engineering Center, Institute of Research and Innovation, Takada, Kashiwa 277-0861, Japan

b. Kashiwa Laboratory, Institute of Research and Innovation

c. Department of Material Science and Engineering, Shibaura Institute of Technology

d. Department of Materials Science and Engineering, Nagoya University

To develop an efficient method to recover Ce from radioactive wastes containing concentrated nitric acid, we have studied the possibility of the combination methods of selective electro-oxidation and anion exchange. The redox reaction behavior of $\mathrm{Ce}(\mathrm{IV}) / \mathrm{Ce}$ (III) in nitric acid solution has been investigated. Anion exchange behavior of $\mathrm{Ce}(\mathrm{IV})$ at various nitric acid concentrations and temperatures was studied. Moreover, separation of Ce(IV) from other rare earth elements was attempted by anion exchanger column.

The results of study by cyclic voltammetry indicate that the kinetics of the $\mathrm{Ce}(\mathrm{IV}) / \mathrm{Ce}$ (III) redox reaction on carbon electrode was significantly promoted by increasing $\mathrm{HNO}_{3}$ concentration, while the formal redox potential remained at almost constant values between $1.34-1.38 \mathrm{~V}(v s . \mathrm{Ag} / \mathrm{AgCl})$. Electrolytic oxidation of $\mathrm{Ce}(\mathrm{III})$ to $\mathrm{Ce}(\mathrm{IV})$ in $6 \mathrm{~mol} \cdot \mathrm{dm}^{-3} \mathrm{HNO}_{3}$ solution was successfully performed with the conversion of $100 \%$ and current efficiency near $60 \%$ by using a novel flow type electrolysis cell containing a carbon-fiber column electrode as working electrode and Vycor Glass(porous silica glass) as separator.

$\mathrm{Ce}(\mathrm{IV})$ showed relatively strong adsorption on AR-01 anion exchanger as the form of nitrato-complexes such as $\mathrm{Ce}\left(\mathrm{NO}_{3}\right)_{5}{ }^{-}$and $\mathrm{Ce}\left(\mathrm{NO}_{3}\right)_{6}{ }^{2-}$ and the distribution coefficient increased with increasing $\mathrm{HNO}_{3}$ concentration. However, the adsorbed $\mathrm{Ce}(\mathrm{IV})$ was reduced to $\mathrm{Ce}(\mathrm{III})$ and eluted into the solution through redox reaction with the anion exchanger. Lowering temperature $(<288 \mathrm{~K})$ can considerably suppress the redox reaction between $\mathrm{Ce}(\mathrm{IV})$ and the anion exchanger. It was found that the separation factor between $\mathrm{Ce}(\mathrm{IV})$ and other trivalent rare earths at $278-288 \mathrm{~K}$ was as high as $25-60$. Separation experiments by AR-01 packed column demonstrated that Ce can be separated with high purity from a nitric acid solution containing $\mathrm{La}(\mathrm{III}), \mathrm{Ce}(\mathrm{III})$ and $\mathrm{Nd}(\mathrm{III})$ after electro-oxidation using the flow type electrolysis cell. The recovery of Ce was $82 \%$ at $278 \mathrm{~K}$, while $\mathrm{La}$ and $\mathrm{Nd}$ were not detected in the recovered Ce product solution.

KEY WORDS : Rare Earth, Ce(IV), Electrolytic Oxidation, Flow-Type Electrolysis Cell, Anion Exchanger, Separation

\section{1. 緒言}

わが国の原子力発電所で発生する使用済核燃料は，再処理工場 においてウランやプルトニウムなどの核分裂性物質を分離回収し て再利用する。現在，使用済核燃料の再処理は，使用済核燃料を 硝酸水溶液で溶解した後，主として PUREX 法と呼ばれる溶媒抽 出法により有用元素の分離回収を行っている。近年，資源の有効

\footnotetext{
* 2002 年 1 月 25 日受付 3 月 13 日受理 資源・素材学会平成 12 年度春季大会 こおいて一部発表

. 普通会員 (財) 産業創造研究所 原子力化学工学センター 研究員

2. 普通会員 工博 (財) 産業創造研究所 原子力化学工学センター 主席研究員

3. 工博 (財) 産業創造研究所柏研究所 所長

4. 芝浦工業大学大学院生 工学研究科材料工学専攻 修士課程

5. 普通会員 工博 名古屋大学教授 大学院工学研究料材料機能工学専攻

[ 著者連絡先] FAX 0471-44-7602(産創研・柏)

[ 著者連絡先 ] FAX 0471-44-7602 (産邻

キーワード: 希土類元素, Ce(IV), 電解酸化, フロー型電解セル,アニオン交換, 分離
}

利用および経済性向上の観点からウラン燃料の燃焼度の増加が進 められている 1)。このような高燃焼度の使用済核然料には比較的 多量のプルトニウムが含まれているため, 現行の溶解方法では難 溶性のプルトニウム酸化物の十分な溶解が困難であり, 溶解槽内 に比較的多量の不溶残涬の発生が懸念されている ${ }^{2)}$ 。プルトニウ 么溶解の促進を図るため, 溶解工程において強酸化性物質である 四価のセリウムイオン ((Ce(IV)) や二価の銀イオン (Ag(II)) を溶解 促進剤として添加することが有効であるとされている ${ }^{3)}$ 。また, 再処理工場の溶解槽や配管に付着した放射性核種の除染剤として 強酸化性の $\mathrm{Ce}(\mathrm{IV})$ を利用することが提案されている4)。なお，セ リウム $(\mathrm{Ce})$ は, 原子炉の中で他の希土類元素とともに核分裂生成 物質として比較的多く生成され，再処理工程において他の核分裂 生成物と共に放射性廃棄物として発生する ${ }^{3)}$ 。上述の再処理廃液 や除染廃液中に含まれる $\mathrm{Ce}$ を他の共存元素から分離回収し, 溶解 
促進剤や除染剤として再利用が可能であれば資源の有効利用およ び放射性廃棄物の削減が期待できると考えられる。

$\mathrm{Ce}$ の分離に関しては，これまで沈殿法，分別結晶法，溶媒抽出

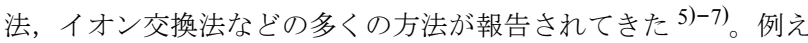
ば中和沈殿法を本研究の処理対象溶液系に適用する場合, 多量の 中和剤を添加する必要があるため, 後処理が困難な二次廃棄物が 多く発生する。また，溶媒抽出法では，同様に難処理性の放射性 有機溶媒廃液が多量に発生する欠点がある。このような観点から， 廃棄物の発生量が少なく,また Ce が高純度に分離回収できる手法 として，イオン交換法が有力な方法であると考えられる。一方， 従来のイオン交換法を利用する希土類分離では，カチオン交換樹 脂による吸着と錯化剂による溶離が行われ 6)8), 隣接する希土類元 素同士の分離係数が $2 \sim 3$ 以下と小さいため, 高効率な分離が困 難であった。また, 本研究の対象処理溶液の硝酸濃度が高く, 力 チオン交換樹脂では多量な $\mathrm{H}^{+}$イオンによる競争吸着のため, $\mathrm{Ce}$ の吸着が妨害される恐れがある。

通常, Ce は水溶液中において他の希土類元素と同様に三価の酸 化状態が最も安定である。一方, 強酸化性条件下において Ce は, 他の希土類元素と違って特異的に四価の酸化状態を示し，これは 硫酸や硝酸水溶液中で比較的安定に存在することが知られてい る。そこで，著者らは，比較的高濃度の硝酸水溶液中で $\mathrm{Ce}(\mathrm{IV})$ が アニオン性のニトラト錯体を形成することに着目し，上述の対象 溶液からのCeの分離回収法として電解酸化法とアニオン交換法を 組み合わせたプロセスについて検討を行っている。本法は，廃棄 物削減の観点から酸化試薬を添加しないで電解酸化法により処理 液中の $\mathrm{Ce}(\mathrm{III})$ を選択的に $\mathrm{Ce}(\mathrm{IV})$ に酸化した後,アニオン交換体に $\mathrm{Ce}(\mathrm{IV})$ を吸着させて分離回収する。そこで本研究では，硝酸水溶 液における $\mathrm{Ce}(\mathrm{IV}) / \mathrm{Ce}(\mathrm{III})$ の電気化学反応特性, 電解酸化法によ る $\mathrm{Ce}(\mathrm{IV})$ の生成挙動および Ce(IV) のアニオン交換特性を調べた。 また, 模擬処理液として Ce(III) と $\mathrm{La}(\mathrm{III}), \mathrm{Nd}(\mathrm{III})$ を含む硝酸水溶 液の電解酸化試験およびイオン交換カラムによる分離試験を行っ た。

\section{2. 実 験 方 法}

\section{$2 \cdot 1$ セリウムの電解実験}

$2 \cdot 1 \cdot 1 \mathrm{Ce}(\mathrm{IV}) / \mathrm{Ce}(\mathrm{III})$ の酸化還元挙動測定サイクリッ クボルタンメトリーにより硝酸水溶液中での $\mathrm{Ce}(\mathrm{IV})$ / Ce (III) の電 気化学反応特性を測定した。測定装置に, (米)BAS 社製のボルタ
ンメトリーアナライザ $(\mathrm{CV}-100 \mathrm{~W})$ を用いた。作用電極に, 直径 3.0 $\mathrm{mm}$ のグラッシーカーボン製の埋込み電極（断面が測定溶液と接 触）を，対極には白金線を，また参照電極には飽和 $\mathrm{Ag} / \mathrm{AgCl}$ 電極 を用いた。測定試料として, $0.1 \sim 6 \mathrm{~mol} \cdot \mathrm{dm}^{-3}$ の硝酸水溶液に $0.5 \mathrm{~mol} \cdot \mathrm{dm}^{-3}$ の $\mathrm{Ce}(\mathrm{III})$ を溶解した溶液を用いた。測定試料は, 測 定前に窒素ガスにより十分に脱気処理を行った。測定は，電位ス イープ速度を $50 \mathrm{mV} \cdot \mathrm{s}^{-1}$ に設定し酸化 $\rightarrow$ 還元の順に掃引させ, $\mathrm{Ce}(\mathrm{IV}) / \mathrm{Ce}(\mathrm{III})$ の酸化還元反応の電流一電位曲線を測定した。

$2 \cdot 1 \cdot 2 \mathrm{Ce}(\mathrm{III})$ から $\mathrm{Ce}(\mathrm{IV})$ への電解酸化実験 硝酸水溶液 中における $\mathrm{Ce}(\mathrm{III})$ から $\mathrm{Ce}(\mathrm{IV}) \sim の$ 電解酸化実験は, 北斗電工 (株) 製のフロー型電解セル (HX-201) を用いて行った。電解装置構成の 概要を Fig.1 に示す。作用電極材に直径約 $10 \mu \mathrm{m}$ のグラッシーカー ボン繊維を用い, その䋊維束を内径 $8 \mathrm{~mm}$, 外径 $10 \mathrm{~mm}$, 長さ 50 $\mathrm{mm}$ の円筒状バイコールガラスカラム内に充填して作用電極とし た。なお，バイコールガラスは平均細孔径が約 $4.5 \mathrm{~nm}$ の多孔性シ リカガラス材で，作用電極の充填カラムと同時に電極間の隔膜と しての役割を果たす。バイコールガラス管の外側に直径 $0.3 \mathrm{~mm} の$ 白金線を巻いて対極とし, 飽和 $\mathrm{Ag} / \mathrm{AgCl}$ 電極を参照電極として用 いた。フロー型電解セルによる電解酸化試験は, 電解液 $(\mathrm{Ce}$ (III) 等 を含む硝酸水溶液 ) をプランジャーポンプにより一定流速でセル の入口より導入し, 通液時にポテンショ/ガルバノスタット ( 北斗 電工製, $\mathrm{HA}-502 \mathrm{G})$ で $+1.5 \mathrm{~V}(v s . \mathrm{Ag} / \mathrm{AgCl})$ の電位を印加し定電位酸 化電解を行った。電解セルからの流出液中の Ce(IV) 濃度は, Fe(II) 標準溶液を用いて酸化還元滴定法 ( 東亜電波製, AUT-301 自動滴 定装置）により測定した。なお，溶液中の $\mathrm{Ce}$ 全濃度は ICP-AES( 島津製作所製，ICPS-1000III）により測定した。

\section{$2 \cdot 2$ イオン交換試験}

$2 \cdot 2 \cdot 1$ イオン交換体および試料溶液 イオン交換試験に は, 本研究で調製した新型高速アニオン交換体 (記号 AR-01) を用 いた。これは, 粒径約 $50 \mu \mathrm{m}$ の多孔性シリカ担体にマクロポア型 (MR 型）アニオン交換樹脂を担持した複合型アニオン交換体であ る。樹脂の基体は, ホルミルスチレンとジビニルベンゼンの共重 合体 (架橋度 $15 \%$ ) であり, 官能基は芳香族アミンである N-メチ ルベンゾイミダゾール基および $\mathrm{N}, \mathrm{N}$ - ジメチルベンゾイミダゾリ ウム基である。その構造と基本物性值を Table 1 に示す。AR-01 は, 化学的に安定な芳香族アミン基を持つ無機担体担持型のパウ ダー状交換体であり, 従来のビーズ状アルキルアミン基アニオン 交換樹脂に比べ速い吸脱着速度, 優れた耐硝酸性および低い通液

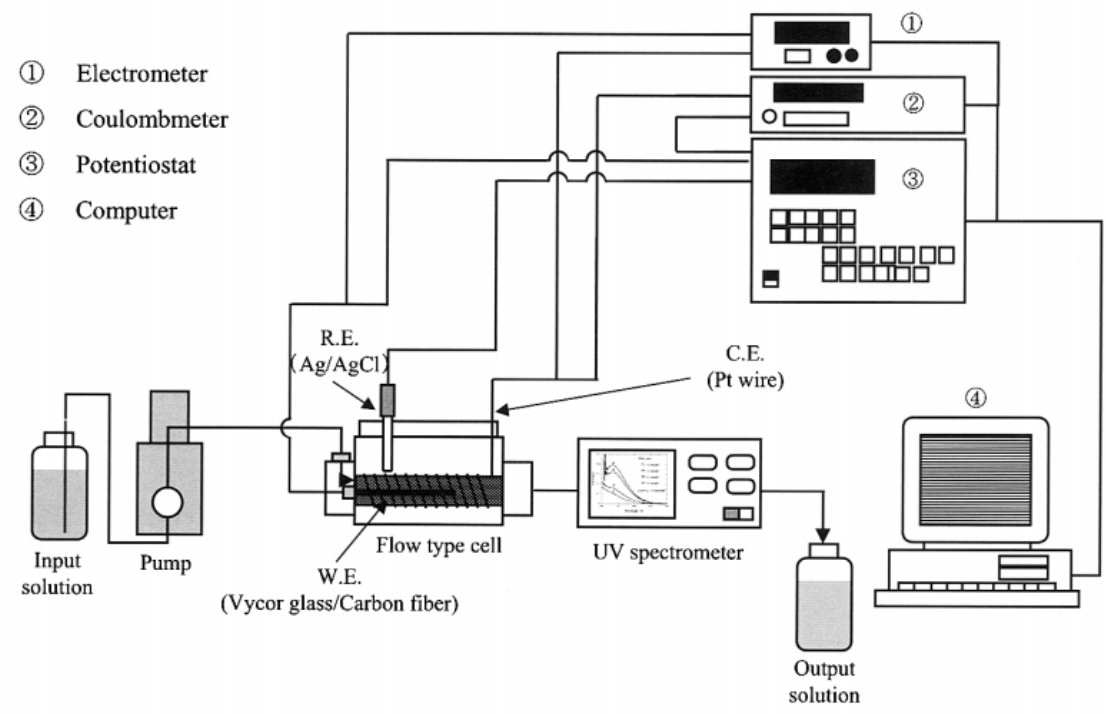

Fig.1 Schematic diagram of the flow type electrolysis apparatus. 
Table 1 Structure and properties of AR-01 anion exchanger.

\begin{tabular}{c|c}
\hline Functional group & SEM \\
\hline $\begin{array}{c}\text { Total capacity (EC) } \\
\text { EC }=N 3+N 4\end{array}$ & $37 \sim 74 \mu \mathrm{m}$ \\
\hline $\begin{array}{c}\text { Quaternary capacity } \\
N 4\end{array}$ & $3.4 \mathrm{meq} \cdot \mathrm{g}^{-1}-\mathrm{Resin}$ \\
\hline $\begin{array}{c}\text { Quaternary ratio } \\
N 4 \%\end{array}$ & $2.0 \mathrm{meq} \cdot \mathrm{g}^{-1}-\mathrm{Resin}$ \\
\hline
\end{tabular}

圧損などの特長を有する。この交換体の合成方法や詳しい構造は すでに報告されている ${ }^{9)-11) 。 ~}$

$\mathrm{La}(\mathrm{III}), \mathrm{Ce}(\mathrm{III}), \mathrm{Nd}(\mathrm{III})$ の各試料溶液は, 各々市販の硝酸塩試 薬 ( 和光純薬特級) を所定濃度の硝酸水溶液に溶解して使用した。

$2 \cdot 2 \cdot 2 \mathrm{Ce}(\mathrm{IV})$ の吸着特性測定 $\mathrm{Ce}(\mathrm{IV})$ の吸着試験は, バッ チ式吸着試験法で行った。吸着試験前に約 $1 \mathrm{~g}$ ( 乾燥重量) の AR01 所定濃度の硝酸水溶液で約 2 時間コンディショニングを行い, 交換基に $\mathrm{NO}_{3}{ }^{-}$イオンを飽和吸着させた。ネジ付き共栓三角フラ スコにコンディショニング後の AR-01 と $5 \mathrm{mmol} \cdot \mathrm{dm}^{-3}$ の金属イ オンを含む所定濃度の硝酸水溶液 $20 \mathrm{~cm}^{3}$ を投入し, 所定温度に調 節した恒温振蕩水槽中に設置して $170 \mathrm{spm}$ の速度で振蕩させた。所 定時間経過後，フィルタ付きマイクロピペットにより吸着後溶液 の上澄み液を採取し，ICP-AES により金属濃度を測定した。なお， 吸着試験溶液中の Ce イオンの酸化状態を確認するため, 上述と同 様に酸化還元滴定法による $\mathrm{Ce}(\mathrm{IV})$ の定量分析を行った。吸着試験 後は, AR-01 を含む試料溶液をガラスフィルタに全量移し, 吸引 濾過により固液分離した。フィルタ上の AR-01 に希硝酸水溶液を 十分に接触させて吸着種を完全に溶離させ, 続いて純水とアセ卜 ンで洗浄した後, $333 \mathrm{~K}$ に調整した真空乾燥機内で一晚乾燥し, AR-01の乾燥重量を秤量した。AR-01 の乾燥重量と基本物性から 樹脂の重量を算出し, 式(1)を用いて吸着分配係数 $\left(K_{d}\right)$ を算出した。 $K_{d}=\frac{C_{0}-C_{S}}{C_{S}} \times \frac{V_{L}}{W_{R}}$

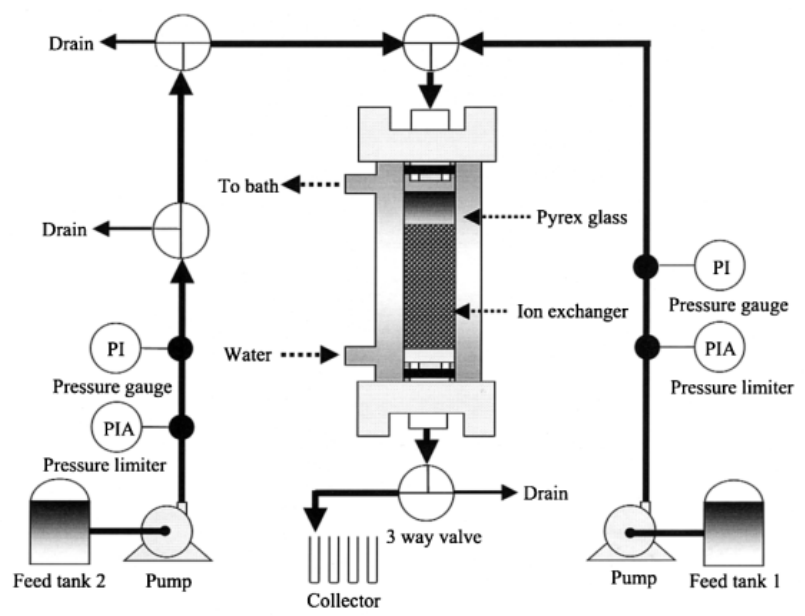

Fig.2 Schematic diagram of the column apparatus for separation experiments.
ここで, $K_{d}$ は分配係数, $C_{0}$ は吸着前溶液中の金属濃度, $C_{S}$ は 吸着後溶液中の金属濃度, $V_{L}$ は溶液体積, $W_{R}$ はイオン交換体の 乾燥重量を表す。

$2 \cdot 2 \cdot 3$ カラム法による $\mathrm{Ce}(\mathrm{IV})$ の分離試験 分離試験用模 擬処理溶液として, 各々 $5 \mathrm{mmol} \cdot \mathrm{dm}^{-3}$ の $\mathrm{Ce}(\mathrm{III}), \mathrm{La}(\mathrm{III}), \mathrm{Nd}(\mathrm{III})$ を含む $6 \mathrm{~mol} \cdot \mathrm{dm}^{-3}$ 硝酸水溶液を調製した。試料溶液を Fig. 1 に示 したフロー型電解セルにより電解酸化を行い, 溶液中の Ce(III) を 完全に Ce(IV) に電解酸化した後, カラム分離試験に供した。カラ ム分離試験装置は, 直径 $10 \mathrm{~mm}$, 高さ $500 \mathrm{~mm}$ のパイレックス製 ガラスカラム, 恒温水循環ジャケット, 送液ポンプ, 圧カリミッ タ, フラクションコレクタ, 恒温水槽等により構成されている。 Fig.2 にカラム分離試験装置の概略図を示す。カラムへの AR-01 交 換体の充填は, 蒸留水によりスラリー状にした AR-01 をカラムの 上方より約 $0.3 \mathrm{MPa}$ の窒素ガス圧力で加圧充填した。分離試験を 行う前に恒温水循環ジャケットに所定温度に調整した蒸留水を循 環させてAR-01 を一定温度に保持させた。分離試験は, 最初に AR01 をコンディショニングするために $6 \mathrm{~mol} \cdot \mathrm{dm}^{-3}$ 硝酸水溶液を定 量ポンプにより流速 $5 \mathrm{~cm}^{3} \cdot \mathrm{min}^{-1}$ ( 以下同) でカラムの上方から供 給し, 交換基に $\mathrm{NO}_{3}{ }^{-}$イオンを飽和吸着させた。次に試料溶液を カラムの上方より $10 \mathrm{~cm}^{3}$ 供給し, 次いで交換体の隙間やカラム壁 面に付着した金属イオンを洗浄するために $6 \mathrm{~mol} \cdot \mathrm{dm}^{-3}$ 硝酸水溶 液を $60 \mathrm{~cm}^{3}$ 通液した。続いて交換体に吸着した金属イオンを溶離 するために, $0.01 \mathrm{~mol} \cdot \mathrm{dm}^{-3}$ の硝酸水溶液を $130 \mathrm{~cm}^{3}$ 通液した。力 ラムの下方から流出する溶液をフラクションコレクタにより 10 $\mathrm{cm}^{3}$ ごとに分画採取した。各フラクション溶液中の金属イオン濃 度は, ICP-AES により測定し分離挙動について検討した。

\section{3. 結果および考察}

\section{$3 \cdot 1$ 硝酸溶液における $\mathrm{Ce}(\mathrm{IV}) / \mathrm{Ce}(\mathrm{III})$ の電気化学反応特性}

本研究の対象溶液は数 $\mathrm{mol} \cdot \mathrm{dm}^{-3}$ 程度の比較的高い硝酸溶液で あり, カーボン纎維電極を作用電極とするフロー型電解セルを用 いて $\mathrm{Ce}(\mathrm{III})$ の電解酸化を行っている。そこで, 本試験ではサイク リックボルタンメトリーにより $0.1 \sim 6 \mathrm{~mol} \cdot \mathrm{dm}^{-3}$ の硝酸水溶液 中におけるカーボン電極上での $\mathrm{Ce}(\mathrm{IV}) / \mathrm{Ce}(\mathrm{III})$ の電気化学反応特 性を調べた。サイクリックボルタンメトリーは, 作用電極の電位 をスイープさせ目的物質の酸化または還元反応が起こった後に電 位のスイープ方向を逆転させ, 溶液と電極との界面で生じる酸化 還元反応特性を調べる方法である。

Fig.3 に電位スイープ速度を $50 \mathrm{mV} ・ \mathrm{~s}^{-1}$ に設定し, 溶液中の硝 酸濃度を変化させて測定した $\mathrm{Ce}(\mathrm{IV}) / \mathrm{Ce}(\mathrm{III})$ の酸化還元反応の電

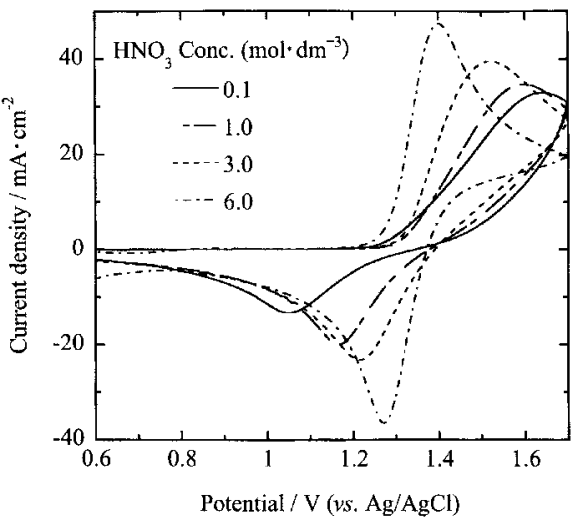

Fig.3 Cyclic voltammograms of Ce(III) in nitric acid solution of various concentrations

$\left(0.5 \mathrm{~mol} \cdot \mathrm{dm}^{-3} \mathrm{Ce}(\mathrm{III})\right.$, Glassy carbon electrode, Scan rate $\left.50 \mathrm{mV} \cdot \mathrm{s}^{-1}, 298 \mathrm{~K}\right)$ 
Table 2 Estimated parameters for $\mathrm{Ce}(\mathrm{IV}) / \mathrm{Ce}(\mathrm{III})$ couple in nitric acid solution from cyclic voltammogram ( $v s . \mathrm{Ag} / \mathrm{AgCl})$

\begin{tabular}{c|c|c|c|c}
\hline $\begin{array}{c}\text { Conc. of } \mathrm{HNO}_{3} \\
\left(\mathrm{~mol} \cdot \mathrm{dm}^{-3}\right)\end{array}$ & $\begin{array}{c}E_{p a} \\
(\mathrm{mV})\end{array}$ & $\begin{array}{c}E_{p c} \\
(\mathrm{mV})\end{array}$ & $\begin{array}{c}\Delta E_{p}=E_{p i}-E_{m i} \\
(\mathrm{mV})\end{array}$ & $\begin{array}{c}E^{\theta} \\
(\mathrm{mV})\end{array}$ \\
\hline 0.1 & 1641 & 1049 & 592 & 1345 \\
\hline 1 & 1600 & 1168 & 432 & 1384 \\
\hline 3 & 1519 & 1233 & 286 & 1376 \\
\hline 6 & 1399 & 1273 & 126 & 1336 \\
\hline
\end{tabular}

流一電位曲線を示す。Fig.3より，各曲線においてそれぞれ Ce(III) $\rightarrow \mathrm{Ce}(\mathrm{IV})$ の酸化反応に対応する酸化波 ( 高電位側) および Ce(IV) $\rightarrow \mathrm{Ce}(\mathrm{III})$ の還元反応に対応する還元波 (低電位側) が観測された。 各濃度の硝酸水溶液中での $\mathrm{Ce}(\mathrm{IV}) / \mathrm{Ce}(\mathrm{III})$ の電流一電位曲線を比 較すると，低濃度の硝酸水溶液中では，ブロードな酸化波および 還元波が確認された。これらは硝酸濃度の増加に伴い鋭いピーク となり，酸化側および還元側でほぼ対称関係となった。これらの 結果により, 溶液中の硝酸濃度の増加に伴い, カーボン電極上に おける $\mathrm{Ce}(\mathrm{IV}) / \mathrm{Ce}(\mathrm{III})$ の酸化還元反応は著しく加速され，また酸 化と還元の可逆性が顕著に増大寸ることが示唆された。可逆系の サイクリックボルタンメトリーにおいて次の関係式により Ce(IV) / Ce(III) の酸化還元反応の形式電位 (この值は近似的に標準酸化還 元電位に相当する) が求められる。

$$
E^{0^{\prime}} \approx E_{1 / 2}=\frac{E_{p a}+E_{p c}}{2}
$$

ここで, $E^{0^{\prime}}$ は酸化還元の形式電位, $E_{1 / 2}$ は半波電位, $E_{p a}$ はピー ク酸化電位, $E_{p c}$ はピーク還元電位を表す。

各濃度の硝酸水溶液において測定した $\mathrm{Ce}(\mathrm{IV}) / \mathrm{Ce}(\mathrm{III})$ の電流一電 位曲線から求めた $E_{p a}, E_{p c}$ および式 (2) より求めた $E_{1 / 2}$ の值を Table 2 に示寸。同表より, 硝酸濃度のピーク電位幅 $\Delta E_{p}$ は硝酸濃 度の増加により顕著に減少し, $\mathrm{HNO}_{3}$ 濃度が $0.1 \mathrm{~mol} \cdot \mathrm{dm}^{-3}$ から 6 $\mathrm{mol} \cdot \mathrm{dm}^{-3}$ に増えることで $\Delta E_{p}$ 值は $592 \mathrm{~V}$ から $126 \mathrm{~V}$ に低減した。 これは硝酸溶液における $\mathrm{Ce}(\mathrm{IV}) / \mathrm{Ce}(\mathrm{III})$ の電極反応に関する Pletcher らの測定結果と同様な傾向を示しており，Ce(IV)/ Ce(III) 間の電荷移動が加速されるためである ${ }^{12)}$ 。なお, Table 2 より, 硝 酸溶液における $\mathrm{Ce}(\mathrm{IV}) / \mathrm{Ce}(\mathrm{III})$ 酸化還元反応の形式電位が 1.34 $1.38 \mathrm{~V}(v s . \mathrm{Ag} / \mathrm{AgCl})$ のほぼ一定值を示し, 硝酸濃度の変化によっ てほとんど変化しないことが認められ, Pletcher らの報告結果とほ ぼ一致している ${ }^{12)}$ 。一般的に支持電解質 (本実験の場合では硝酸 ) 濃度の増加により, 溶液の粘性度が増大寸ることによってイオン の拡散速度が減少し，このためピーク電流值が低下寸ると報告さ れている ${ }^{12)}$ 。著者らは，硫酸溶液におけるグラッシカーボン繊維 電極上での $\mathrm{Ce}(\mathrm{IV}) / \mathrm{Ce}(\mathrm{III})$ の酸化還元反応について測定した結果, 硫酸濃度の増加により $E_{p a}$ および $E_{p c}$ の低下が認められた ${ }^{13)}$ 。し かし，Fig.3 および Table 2 に示された測定結果から明らかなよう に，本実験では硝酸濃度の増加による $\mathrm{Ce}(\mathrm{IV}) / \mathrm{Ce}(\mathrm{III})$ 間の酸化還 元反応のピーク電流值の顕著な増大が認められた。これは，硝酸 溶液における $\mathrm{Ce}^{4+}$ イオンと $\mathrm{NO}_{3}{ }^{-}$との強い錯形成反応 ${ }^{14)}$ による ものと推察されるが, これについて今後さらに究明する必要があ る。

上述したように, 硝酸濃度の上昇により $\mathrm{Ce}(\mathrm{IV}) / \mathrm{Ce}(\mathrm{III})$ の酸化 還元電位がほとんど変化せず，また酸化還元反応が加速されるこ とから, 比較的高濃度の硝酸水溶液においてカーボン電極を用い, 酸化電位約 $1.4 \mathrm{~V}(v s . \mathrm{Ag} / \mathrm{AgCl})$ 以上の条件下で電解酸化法により $\mathrm{Ce}(\mathrm{III})$ から $\mathrm{Ce}(\mathrm{IV}) \sim の$ 電解酸化が十分可能であると考えられる。

\section{$3 \cdot 2$ フロー型電解セルを用いた $\mathrm{Ce}(\mathrm{III})$ の電解酸化試験}

本実験では，カーボン繊維電極を作用電極に，バイコールガラ スを隔膜とするフロー型電解セルによる $\mathrm{Ce}(\mathrm{III})$ から $\mathrm{Ce}(\mathrm{IV})$ 一の電

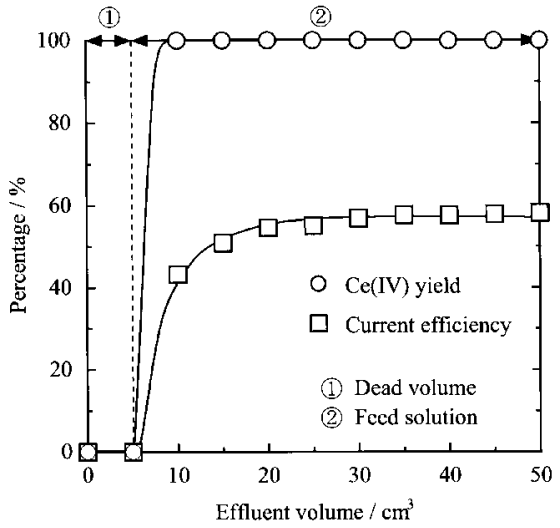

Fig.4 Electrolytic oxidation behavior of Ce(III) in nitric acid solution using the flow type electrolysis cell.

(Feed solution : $5 \mathrm{mmol} \cdot \mathrm{dm}^{-3} \mathrm{Ce}(\mathrm{III})-6 \mathrm{~mol} \cdot \mathrm{dm}^{-3} \mathrm{HNO}_{3}$, Flow rate $1 \mathrm{~cm}^{3} \cdot \mathrm{min}^{-1}$, Potential : $+1.5 \mathrm{~V}(\mathrm{vs} . \mathrm{Ag} / \mathrm{AgCl})$, Temperature $\left.: 298 \mathrm{~K}\right)$

解酸化試験を行った。フロー型電解セルは電解溶液を通液し, 液 の流れ方向に直流電位を印加することで連続的に電気分解を行う ことができる。このフロー型電解セルの最大の特長は, 極めて大 きな比表面積 (容積 $1 \mathrm{~cm}^{3}$ 当たり約 $1,500 \mathrm{~cm}^{2}$ ) を有するカーボン緎 維を密に充填したカラム型電極を作用電極として用いることであ る。そのため作用電極を通過する電解液の容積に対する電極表面 積の割合が圧倒的に大きく, 被電解物質が迅速かつ高効率に電解 することができる ${ }^{15)}$ 。著者らは，このようなフロー型電解セルを 用いて, 硝酸水溶液中において高濃度の U(VI) を極めて高効率で $\mathrm{U}(\mathrm{IV})$ に電解還元できることを確認した ${ }^{16) 17)}$

$\mathrm{Ce}(\mathrm{III})$ の電解酸化試験は, $3 \cdot 1$ の検討結果より作用電極の電位 を $1.5 \mathrm{~V}(v \mathrm{~s} . \mathrm{Ag} / \mathrm{AgCl})$ に設定し定電位電解法で行った。Fig.4に 5 $\mathrm{mmol} \cdot \mathrm{dm}^{-3} \mathrm{Ce}(\mathrm{III})$ を含む $6 \mathrm{~mol} \cdot \mathrm{dm}^{-3}$ 硝酸水溶液中における $\mathrm{Ce}(\mathrm{III})$ の電解酸化試験の結果を示す。同図より, 本実験の条件下で試料 溶液を一回のみセルに通過させることで溶液中の Ce(III) が完全に $\mathrm{Ce}(\mathrm{IV})$ に電解酸化されたことが認められた。なお, 本試験の電解 電位は, 水の分解電位 ( 約 $1.0 \mathrm{~V} v$ s. $\mathrm{Ag} / \mathrm{AgCl}$ )をはるかに超えてお り, 水の電気分解反応による少量の酸素発生も観測されていた。 しかしながら, Ce(III) 電解酸化の電流効率が約 $60 \%$ で比較的高い 值が維持され, 電解酸化が効果的に行われることが確認された。

\section{$3 \cdot 3 \mathrm{Ce}(\mathrm{IV})$ のアニオン交換挙動}

3 ・2 の実験結果により, 硝酸水溶液中においてフロー型電解セ ルを用いた電解酸化法により $\mathrm{Ce}(\mathrm{IV})$ が比較的容易に生成できるこ とが明らかとなった。本研究では電解酸化により生成された $\mathrm{Ce}$ (IV) を化学除染剤や溶解促進剂として使用した後, アニオン交 換法を用いて他の希土類等の共存元素から分離回収して再利用す ることを想定している。前報 ${ }^{14)}$ により, 約 $3 \mathrm{~mol} \cdot \mathrm{dm}^{-3}$ 以上の硝 酸水溶液中で $\mathrm{Ce}(\mathrm{IV})$ は $\mathrm{NO}_{3}{ }^{-}$との結合により $\mathrm{Ce}\left(\mathrm{NO}_{3}\right)_{5}{ }^{-}$や $\mathrm{Ce}\left(\mathrm{NO}_{3}\right)_{6}{ }^{2-}$ といった高配位のアニオン性ニトラト錯体を形成する ことが認められた。本研究では, このような特異的な高酸化状態 の $\mathrm{Ce}(\mathrm{IV})$ と硝酸イオンとの強い錯形成能力を利用し, アニオン交 換法による $\mathrm{Ce}$ と他の三価希土類イオンとの分離可能性を検討し た。

まず硝酸水溶液中において AR-01 交換体による Ce(IV) の吸着 特性を調べた。Fig.5 に温度 $333 \mathrm{~K}$ において溶液中の硝酸濃度を変 えて測定した $\mathrm{Ce}(\mathrm{IV})$ の AR-01 交換体への吸着分配係数の経時変化 挙動を示す。Fig.5 より, 硝酸濃度が高いほど, Ce(IV)の吸着分配 係数が大きくなることが認められた。これは, 硝酸イオン濃度の 増加に伴い，溶液中に上記高配位のアニオンニトラト錯体の生成 率が増加寸るためであると考えられる ${ }^{14)}$ 。なお，Fig.5 に示した 


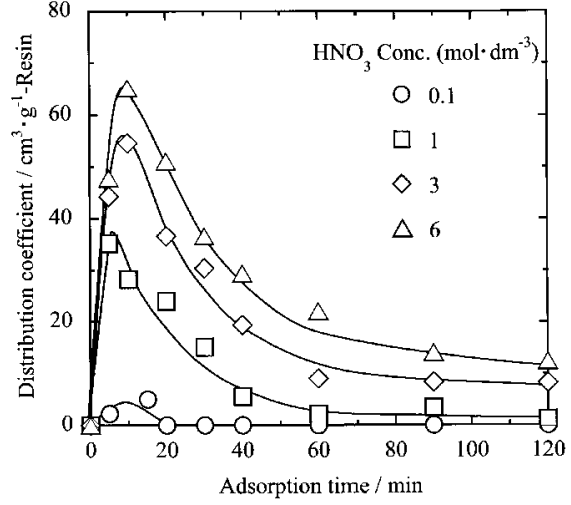

Fig.5 Time evolution of Ce(IV) adsorption from nitric acid solution onto AR-01 anion exchanger. $\left(5 \mathrm{mmol} \cdot \mathrm{dm}^{-3} \mathrm{Ce}(\mathrm{IV}), 333 \mathrm{~K}\right)$

$\mathrm{Ce}(\mathrm{IV})$ の吸着特性において最も特徵的なのは, 分配係数の経時変 化挙動である。通常，イオン交換体への吸着成分の吸着は時間の 経過とともに増加し, やがて吸着平衡状態に達して分配係数が一 定值になる。 Ce(IV) の吸着は吸着初期では時間とともに顕著に増 大し，10〜 15 min で最大の分配係数に達し，その後時間の経過に つれて著しく低下してくることが認められた。これは $\mathrm{Ce}(\mathrm{IV})$ の強 い酸化力に起因するものと考えられ，交換体にいったん吸着され た Ce(IV)が交換体との酸化還元反応により非吸着性の Ce(III)に還 元されて溶出するものと推察される。

次に, AR-01 交換体による $\mathrm{Ce}(\mathrm{IV})$ 吸着挙動の温度依存性を調心 た。Fig. 6 に硝酸濃度を $6 \mathrm{~mol} \cdot \mathrm{dm}^{-3}$ に固定し, 吸着温度を 278 $333 \mathrm{~K}$ の範囲で変化させて測定した分配係数の経時変化挙動を示 す。Fig.6 より，303 K, $318 \mathrm{~K}, 333 \mathrm{~K}$ の比較的高い温度領域にお いて，吸着初期では分配係数は吸着時間とともに顕著に増大寸る が，やがて吸着ピークを示した後，分配係数が時間の経過ととも に減少していくことが認められた。なお, 温度が高いほど吸着ピー ク出現の吸着時間が短く, しかも吸着ピーク経過後の分配係数低 下の度合いが大きかった。一方， $278 \mathrm{~K} ， 288 \mathrm{~K}$ の比較的低い温度 領域では，吸着ピークがほとんど見られず，分配係数は吸着時間 とともに増加し, 約 $60 \mathrm{~min}$ 後にほぼ一定值となった。これらの結 果はイオン交換体との酸化還元反応による $\mathrm{Ce}(\mathrm{IV})$ から $\mathrm{Ce}(\mathrm{III})$ 一の 還元速度は温度上昇によって著しく促進されることを示唆した。

このように, 硝酸溶液における $\mathrm{Ce}(\mathrm{IV})$ のアニオン交換反応系で は, 錯形成, 吸脱着, 酸化還元を含む極めて複雑な複合反応系で ある。これらの反応の平衡定数や速度定数は強い温度依存性を 持っている。一般的に, 反応速度は正の温度依存性 ( 温度上昇に よって促進される）を持っている。また，錯形成反応や酸化還元 反応の平衡定数は正の温度依存性を持つ場合が多く, これに対し イオン交換反応 (吸着反応) の平衡定数は負の温度依存性を示す 場合が多い。これらの複数因子の相互作用により, 硝酸溶液にお ける Ce(IV)のアニオン交換体への吸着挙動は Fig.5, Fig.6 に示さ れたように温度, 硝酸濃度によって複雑な挙動を呈している。

一方, Fig.6 に示されたように, 温度 $288 \mathrm{~K}$ 以下の温度において 実験した 2 時間の範囲では AR-01 交換体への Ce(IV) 吸着分配係数 が時間の経過と共に低下寸ることがなく，すなわちこのような比 較的低い温度領域では吸着した $\mathrm{Ce}(\mathrm{IV})$ と交換体との酸化還元反 応が極めて緩やかであると考えられる。なお， $278 \mathrm{~K}$ と $288 \mathrm{~K}$ に おいて $6 \mathrm{~mol} \cdot \mathrm{dm}^{-3}$ 硝酸における $\mathrm{Ce}(\mathrm{IV})$ の分配係数が $50 \sim 60$ $\mathrm{cm}^{3} \cdot \mathrm{g}^{-1}$ の比較的強い吸着性を示している。一方, 硝酸溶液中で は Ce (III) および他の三価希土類イオンの分配係数は $1 \sim 2 \mathrm{~cm}^{3}$.

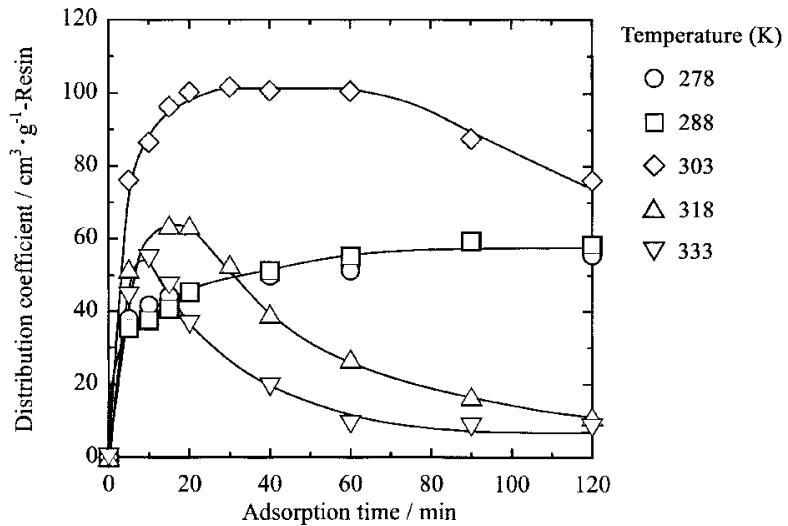

Fig.6 Time evolution of Ce(IV) adsorption from nitric acid solution onto AR-01 anion exchanger at various temperatures. $\left(5 \mathrm{mmol} \cdot \mathrm{dm}^{-3} \mathrm{Ce}(\mathrm{IV}), 6 \mathrm{~mol} \cdot \mathrm{dm}^{-3} \mathrm{HNO}_{3}\right)$

$\mathrm{g}^{-1}$ 以下である ${ }^{10)}$ 。したがって AR-01アニオン交換体による Ce(IV) と他の三価希土類イオンとの分離係数は約 $25 \sim 60$ に達している。

\section{$3 \cdot 4 \mathrm{Ce}(\mathrm{IV})$ と他の希土類元素の分離挙動}

$3 \cdot 2$ で述べたように, カーボン繊維を作用電極とするフロー型 電解セルを用いて硝酸溶液中の Ce(III) を効果的に Ce(IV) に電解酸 化することができる。なお, Ce 以外の希土類元素は水溶液中では 四価あるいはそれ以上の高酸化状態が存在しないことが知られて いる。したがって Ce(III) と他の三価希土類が共存する硝酸溶液に おいて, 電解酸化法により $\mathrm{Ce}(\mathrm{III})$ を選択的に Ce(IV) に酸化するこ とが可能である。また， $3 \cdot 3$ の検討結果により, 硝酸溶液中にお いて Ce(IV) はアニオン性ニトラト錯体として AR-01アニオン交換 体に比較的強い吸着性を示し, 他の非吸着性三価希土類元素から 分離することが可能であることが示された。そこで, 本実験では 電解酸化法とアニオン交換分離法との組み合わせによる硝酸溶液 中の $\mathrm{Ce}(\mathrm{III})$ と従来相互分離が困難な $\mathrm{La}(\mathrm{III}), \mathrm{Nd}(\mathrm{III})$ などの原子番 号が接近している軽希土類元素との分離を試みた。

$\mathrm{La}(\mathrm{III}), \mathrm{Ce}(\mathrm{III}), \mathrm{Nd}(\mathrm{III})$ をそれぞれ $5 \mathrm{mmol} \cdot \mathrm{dm}^{-3}$ 含む $6 \mathrm{~mol}$ ・ $\mathrm{dm}^{-3} \mathrm{HNO}_{3}$ 溶液をフロー型電解セルにより電解酸化を行い, 溶液 中の $\mathrm{Ce}$ (III) を完全に Ce(IV) に酸化した後, AR-01 アニオン交換カ ラムにより分離試験を行った。Fig.7に温度 $298 \mathrm{~K}$ において行った 分離試験の結果を示す。同図より $\mathrm{La}$ および $\mathrm{Nd}$ は交換体にほとん ど吸着されず, 試料溶液およびこれに続く $6 \mathrm{~mol} \cdot \mathrm{dm}^{-3} \mathrm{HNO}_{3}$ 洗浄 液の供給によりカラムから全量流出した。試料溶液中の約 $65 \%$ の $\mathrm{Ce}$ は交換体に吸着され, 次いで $10 \mathrm{mmol} \cdot \mathrm{dm}^{-3}$ の希 $\mathrm{HNO}_{3}$ 溶液

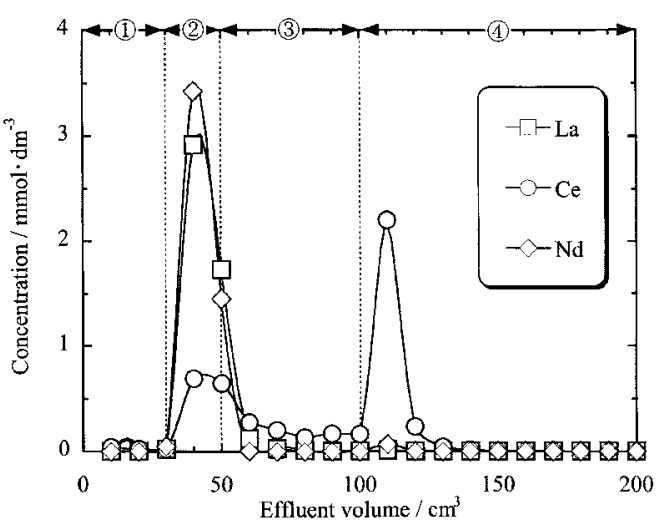

Fig.7 Results of separation experiment for a Ce, $\mathrm{La}$ and $\mathrm{Nd}$ containing nitric acid solution at $298 \mathrm{~K}$ after electro-oxidation. (1) Dead volume (2) Feed solution (3) $6 \mathrm{~mol} \cdot \mathrm{dm}^{-3} \mathrm{HNO}_{3}$ (4) 10 $\mathrm{mmol} \cdot \mathrm{dm}^{-3} \mathrm{HNO}_{3}$, Feed solution: $5 \mathrm{mmol} \cdot \mathrm{dm}^{-3}(\mathrm{La}, \mathrm{Ce}$, $\mathrm{Nd})-6 \mathrm{~mol} \cdot \mathrm{dm}^{-3} \mathrm{HNO}_{3}$, Flow rate: $5 \mathrm{~cm}^{3} \cdot \mathrm{min}^{-1}$ 


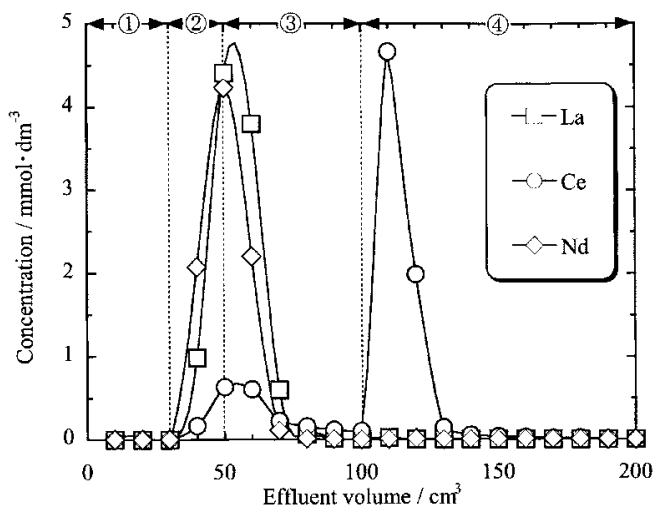

Fig.8 Results of separation experiment for a $\mathrm{Ce}, \mathrm{La}$ and $\mathrm{Nd}$ containing nitric acid solution at $278 \mathrm{~K}$ after electro-oxidation.

(1) Dead volume (2) Feed solution (3) $6 \mathrm{~mol} \cdot \mathrm{dm}^{-3} \mathrm{HNO}_{3}$ (4) 10 $\mathrm{mmol} \cdot \mathrm{dm}^{-3} \mathrm{HNO}_{3}$, Feed solution: $5 \mathrm{mmol} \cdot \mathrm{dm}^{-3}(\mathrm{La}, \mathrm{Ce}$, $\mathrm{Nd})-6 \mathrm{~mol} \cdot \mathrm{dm}^{-3} \mathrm{HNO}_{3}$, Flow rate: $5 \mathrm{~cm}^{3} \cdot \mathrm{min}^{-1}$

を溶離剤として通液することにより吸着したCeが速やかに溶離さ れた。これはアニオン性の $\mathrm{Ce}(\mathrm{IV})$ ニトラト錯体として交換体に吸 着されたもので，希硝酸の供給により交換体吸着サイト近傍の溶 液中の $\mathrm{NO}_{3}{ }^{-}$濃度の低下によりニトラト錯体が $\mathrm{Ce}^{4+}$ や $\mathrm{Ce}\left(\mathrm{NO}_{3}\right)^{3+}$ といったカチオン種に解離して溶離されたものと考えられる。一 方, 供給試料溶液中の $\mathrm{Ce}$ の約 $35 \%$ ほどが吸着されずに試料溶液 および $6 \mathrm{~mol} \cdot \mathrm{dm}^{-3} \mathrm{HNO}_{3}$ 洗浄液と共にカラムから流出し, 上記非 吸着性の $\mathrm{La}, \mathrm{Nd}$ 流出液に混入した。これは, 交換体との接触に より一部の Ce(IV)が非吸着性の Ce(III)に還元されたものと推察さ れる。

分離試験の温度を $278 \mathrm{~K}$ にケげて Fig.7 と同様な分離試験を行っ た結果をFig.8に示す。Fi.g8 より各元素の吸着・溶離挙動は Fig.7 に示された結果と類似しているが，La-Nd に混入した非吸着性 Ce の量は顕著に減少し，全 $\mathrm{Ce}$ 量の約 $18 \%$ であった。すなわち $82 \%$ の Ce 回収率が得られた。これは $3 \cdot 3$ で述べたように, 交換体と の接触による $\mathrm{Ce}(\mathrm{IV})$ から $\mathrm{Ce}(\mathrm{III})$ への還元は, 温度の低下によって 抑制されるためである。なお，溶離回収された $\mathrm{Ce}$ 溶液中には $\mathrm{La}$ と $\mathrm{Nd}$ が全く検出されず，すなわち高純度の $\mathrm{Ce}$ 溶液として分離回 収されることが確認された。これらの試験結果から, 電解酸化法 とアニオン交換法の組み合わせにより Ceと他の希土類元素を含む 硝酸溶液からCeを比較的効率よく高純度で分離回収することが示 された。今後さらに分離条件等を検討し Ce 回収率の向上を図ると ともに, $\mathrm{Ce}(\mathrm{IV})$ による交換体の劣化挙動を検討・評価する必要が ある。またこれらの結果を基に，前述した核燃料再処理廃液や除 染廃液からのCeの分離回収方法としての適用性をさらに検討する 予定である。

\section{4. 結言}

本研究では, 硝酸溶液における $\mathrm{Ce}(\mathrm{III})$ から $\mathrm{Ce}(\mathrm{IV})$ 一の電解酸化 挙動を検討し，またアニオン交換体による Ce(IV) の吸着挙動およ びCe(IV) と他の希土類元素との分離性能を調べ, 次のような結論 が得られた。
（1）溶液中の硝酸濃度の上昇に伴い，カーボン電極上における $\mathrm{Ce}(\mathrm{IV}) / \mathrm{Ce}(\mathrm{III})$ の酸化還元反応速度は顕著に増加し, また酸化と還 元の可逆性が増大寸ることが認められた。なお, $\mathrm{Ce}(\mathrm{IV}) / \mathrm{Ce}(\mathrm{III})$ の 形式電位は硝酸濃度にほとんど依存せず, 約 $1.34 \sim 1.38 \mathrm{~V}(\mathrm{vs} . \mathrm{Ag} /$ $\mathrm{AgCl})$ の一定值を示している。

（2）カーボン繊維を作用電極に，バイコールガラスを隔膜とす るフロー型電解セルを用い, $1.5 \mathrm{~V}(v s . \mathrm{Ag} / \mathrm{AgCl})$ の定電位電解によ り $6 \mathrm{~mol} \cdot \mathrm{dm}^{-3}$ 硝酸水溶液中の $\mathrm{Ce}(\mathrm{III})$ を完全に $\mathrm{Ce}(\mathrm{IV})$ に電解酸化 寸ることが認められ，約 $60 \%$ の比較的高い電流効率が得られた。

（3） AR-01交換体による硝酸水溶液からの Ce(IV)の吸着分配係 数は硝酸濃度の上昇により増大し, $\mathrm{Ce}\left(\mathrm{NO}_{3}\right)_{5}{ }^{-}$や $\mathrm{Ce}\left(\mathrm{NO}_{3}\right)_{6}{ }^{2-}$ など のアニオン性ニトラト錯体として吸着されるものと考えられる。 なお， $\mathrm{Ce}(\mathrm{IV})$ の吸着特性は温度によって著しく変化し， $303 \mathrm{~K}$ 以 上の比較的高い温度領域ではいったん吸着した Ce(IV) は交換体と の酸化還元反応により非吸着性の $\mathrm{Ce}(\mathrm{III})$ に還元されて溶出するこ とが確認された。一方, 交換体における Ce(IV) から Ce(III) 一の還 元は温度の低下によって顕著に抑制され, 約 $288 \mathrm{~K}$ 以下の比較的 低い温度領域では分配係数が $50 \sim 60 \mathrm{~cm}^{3} \cdot \mathrm{g}^{-1}$ のほぼ一定值を示 し,他の三価希土類イオンとの分離係数が約 $25 \sim 60$ に達している。

(4) $\mathrm{La}(\mathrm{III}), \mathrm{Ce}(\mathrm{III}), \mathrm{Nd}(\mathrm{III})$ を含む $6 \mathrm{~mol} \cdot \mathrm{dm}^{-3}$ 硝酸溶液を上 記フロー型電解セルにより $\mathrm{Ce}(\mathrm{III})$ を選択的に $\mathrm{Ce}(\mathrm{IV})$ に電解酸化し た後, AR-01 交換体を充填したカラムを用いて分離試験を行った 結果, $\mathrm{Ce}$ が他の希土類元素から高純度に分離されることが認めら れた。なお, 分離操作温度を $298 \mathrm{~K}$ から $278 \mathrm{~K}$ に下げることで $\mathrm{Ce}$ の回収率が約 $65 \%$ から $82 \%$ に上昇した。電解酸化法とアニオン 交換法との組み合わせにより, 核燃料再処理廃液や除染廃液中に 含まれるCeを他の希土類等の共存元素から高純度に分離回収でき る可能性が示唆された。

\section{引用 文 献}

1) 日本原子力学会: 最新核燃料工学一高度化の現状と展望一, p. 19, (2001)

2) 日本原子力学会 : プルトニウム燃料工学, p. 167,(1998)

3) Benedict, M., Pigford, T.H. and Levi, H.W. : Nuclear Chemical Engineering, McGrawHill, New York, p. 338, 477, (1981)

4) Bray, L.A. and Ryan, L. : Radioactive Waste Management, Harwood Academic Pub., London, Vol. 6, p. 129, (1982)

5) Eyring, L., ed. : Progress in the Science and Technology of the Rare Earth , John Wiley \& Sons Inc., New York, p. 129, (1968)

6) Topp, N. E. ( 塩川二郎, 足立吟也訳 ) : 希土類元素の化学, 化学同人, p. 32, 46$49,(1980)$

7）加納 剛・柳田博明 編: レアアースーその物性と応用一, 技報堂, p. 93, (1983)

8) 足立吟也 監修: 希土類物語一先端技術の魔術師一, 産業図書, p. 20-22, (1992)

9) 新井 剛・武田邦彦・韋悦周・熊谷幹郎・高島洋一：日本イオン交換学会誌, Vol. 6(3), p. 90-107, (1995)

10) Wei, Y. Z., Kumagai, M., Takashima, Y., Asou, M., Namba, T., Suzuki, K., Maekawa, A. and Ohe, S. : J. Nucl. Sci. Technol., Vol. 35, p. 357-364, (1998)

11）岩佐 敏・新井 剛・韋悦周・熊谷幹郎・村田 清・武田邦彦: 日本イオン交 換学会誌, Vol. 12, p. 40-46, (2001)

12) Pletcher, D. and Valdes, E. M.: Electrochemica Acta, Vol. 33, p. 499-507, (1988)

13）韋悦周・新井 剛 - 熊谷幹郎 - Navratil, J. D. and Creager, S. E. : NEDO 平成 12 年 度国際共同研究提案公募事業成果報告会予稿集, p. 124-129, (2002)

14）三瓶友広・新井 剛・韋悦周・熊谷幹郎・武田邦彦：日本イオン交換学会誌, Vol. 13(1), p. 2-9, (2002)

15）木原壮林・吉田善行・青柳寿夫 : 分析化学, Vol. 40, p. 309-323, (1991)

16）新井剛・韋悦周・熊谷幹郎・高島洋一: 資源・素材学会平成 13 年度春季大会 講演要旨集, p. $84-85,(2001)$

17) Arai, T., Wei, Y.Z., Kumagai, M. and Takashima, Y. : Proc. Int. Conf. of GLOBAL'2001(9-13, Sep., Paris), No.004, (2001) 